\title{
The Impact of Rural Informal Finance on the Growth of Farmers' Household Income
}

\author{
Xi Shen, Kun Song (Corresponding Author) \\ School of Economics, Sichuan Agricultural University, Chengdu, Sichuan, \\ 611130
}

\begin{abstract}
Based on the relevant time series data from 1984 to 2015, this paper constructs a VAR model to analyze the relationship between the rural informal financial scale and the farmers' household income growth. The results show that rural informal finance has a significant effect on promoting the growth of farmer's household income, even more than that of formal financial support. In the long run, the rural informal financial scale has certain influence on the farmer's household income, but the impact is limited. Therefore, while actively guiding the development of rural informal finance, we should continue to deepen rural financial reform and accelerate rural financial innovation.
\end{abstract}

Keywords: Rural informal finance, Rural household income, VAR model

\section{Introduction}

In the past three years, the income structure of peasants has been changed, but the family income is still the main source of farmers' income and the main way to get the income of most farmers. To promote the steady growth of farmer's family income is the problem of increasing farmers' income. As an important factor in the development of rural economy, rural financial elements play an increasingly important role in the process of increasing farmers' income. However, under the background of the rural financial repression in our country, the funds hunger restricts the development of the rural economy. The farmers are faced with credit constraints and lack of financial support. They are still systematic in nature and lead to the deterioration of their own "blood-producing" development mechanism. 
The intrinsic self-development function is lost and the income of family business is difficult to improve. Hu Tsung-yi and Liu Can (2014) show that there is spatial polarization of peasants' income in our country, and informal finance plays an important role in increasing peasants' income. It can be seen that rural informal finance contributes much to residents' income increase. Informal finance refers to financial transactions, loans and deposits that occur outside the supervision of central monetary authorities or financial market authorities (Adams and Fitchett, 1992). Rural informal finance refers to indirect financing provided by nonstatutory financial organizations in rural areas or borrowing on condition of repayment between peasants, farmers and rural entrepreneurs. Household income refers to the income from the production and operation of farmers' households. Throughout the existing research, not difficult to find: First, from the perspective of revenue sources structure for the farmers into the family business income, empirical analysis of the literature is relatively small. Second, the existing method of estimating the size of informal finance uses data only as of 2010. It is of great practical significance to correctly evaluate the current situation of rural informal finance and to grasp the problems existing in the rural financial system.

\section{The empirical analysis}

\subsection{Iindicators of choice, data sources}

The data are mainly from China Rural Statistical Yearbook, China Statistical Yearbook, China Agricultural Yearbook and China Financial Statistical Yearbook.

The explanatory variable: The income level of the rural household as an explanatory variable Per Capita Net Income of Rural Households / Per Capita Net Income of Rural Households. Using HI and 100 consumer price index for the reduction, to eliminate the impact of price factors. 2. The main explanatory variables: the explanatory variable is the rural informal finance scale, the size of the calculation reference Song Kun (2016) algorithm. With. 3. There are three control variables: formal financial scale. The level of fixed asset investment, used to indicate. The level of financial support for agriculture, with said.

\subsection{Unit root test}

Unit root test results in Table 1. Therefore, the rejection variable has a unit root of the original hypothesis, can be co-integration test. 
Table 1 The unit root test of variables

\begin{tabular}{|c|c|c|c|c|c|}
\hline $\begin{array}{l}\text { varia } \\
\text { ble }\end{array}$ & $\begin{array}{c}\mathrm{ADF} \\
\text { statistics }\end{array}$ & $\begin{array}{c}1 \% \\
\text { threshold }\end{array}$ & $\begin{array}{c}5 \% \\
\text { threshold }\end{array}$ & $\begin{array}{l}10 \% \text { critical } \\
\text { value }\end{array}$ & $\begin{array}{l}\text { conclusi } \\
\text { on }\end{array}$ \\
\hline$(\mathrm{c}, \mathrm{t}, \mathrm{o}$ & 0.497874 & $\begin{array}{c}- \\
3.661661\end{array}$ & $\begin{array}{c}- \\
2.960411\end{array}$ & -2.619160 & $\begin{array}{r}\text { Not } \\
\text { smooth }\end{array}$ \\
\hline $\begin{array}{l}\text { (c,n, } \\
\text { o) }\end{array}$ & 3.937615 & $\begin{array}{c}- \\
3.670170\end{array}$ & $\begin{array}{c}- \\
2.963972\end{array}$ & -2.621007 & smooth \\
\hline $\begin{array}{l}\text { (c,n, } \\
\text { o) }\end{array}$ & -1.770016 & $\begin{array}{c}- \\
3.661661\end{array}$ & $\begin{array}{c}- \\
2.960411\end{array}$ & -2.619160 & $\begin{array}{r}\text { Not } \\
\text { smooth }\end{array}$ \\
\hline $\begin{array}{l}\text { (c,n, } \\
\text { o) }\end{array}$ & -4.333781 & $\begin{array}{c}- \\
3.670170\end{array}$ & $\begin{array}{c}- \\
2.963972\end{array}$ & -2.621007 & smooth \\
\hline$(\mathrm{c}, \mathrm{t}, \mathrm{o}$ & -2.490228 & $\begin{array}{c}- \\
4.284580\end{array}$ & $\begin{array}{c}- \\
3.562882\end{array}$ & -3.215267 & $\begin{array}{r}\text { Not } \\
\text { smooth }\end{array}$ \\
\hline $\begin{array}{l}\text { (c,n, } \\
\text { o) }\end{array}$ & -6.456231 & $\begin{array}{c}- \\
3.670170\end{array}$ & $\begin{array}{c}- \\
2.963972\end{array}$ & -2.621007 & smooth \\
\hline$(\mathrm{c}, \mathrm{t}, \mathrm{o}$ & -3.002284 & $\begin{array}{c}- \\
4.284580\end{array}$ & $\begin{array}{c}- \\
3.562882\end{array}$ & -3.215267 & $\begin{array}{r}\text { Not } \\
\text { smooth }\end{array}$ \\
\hline $\begin{array}{l}\text { (c,n, } \\
\text { o) }\end{array}$ & -9.213324 & $\begin{array}{c}- \\
3.670170\end{array}$ & $\begin{array}{c}- \\
2.963972\end{array}$ & -2.621007 & smooth \\
\hline$(\mathrm{c}, \mathrm{t}, \mathrm{o}$ & -2.156691 & $\begin{array}{c}- \\
4.284580\end{array}$ & $\begin{array}{c}- \\
3.562882\end{array}$ & -3.215267 & $\begin{array}{r}\text { Not } \\
\text { smooth }\end{array}$ \\
\hline $\begin{array}{l}\text { (c,n, } \\
\text { o) }\end{array}$ & -6.356982 & $\begin{array}{c}- \\
3.670170 \\
\end{array}$ & $\begin{array}{c}- \\
2.963972 \\
\end{array}$ & -2.621007 & smooth \\
\hline
\end{tabular}

Note: C, T, 1, 2, 3 respectively represent the constant term, trend term, lag phase 1, lag phase 2 and lag phase 3 respectively.

\subsection{Johansen cointegration test}

The cointegration equation set in the test should contain an intercept term. The Johannsen cointegration test results are shown in Table 2. Table 2 VAR model hysteresis order selection

\begin{tabular}{ccccccc}
\hline Lag & LogL & LR & FPE & AIC & SC & HQ \\
\hline 0 & 285.4662 & NA & $6.53 e-16$ & -20.77527 & -20.53530 & -20.70392 \\
1 & 308.6564 & 36.07363 & $7.76 e-16$ & -20.64121 & -19.20139 & -20.21308 \\
2 & 331.5721 & 27.15935 & $1.12 \mathrm{e}-15$ & -20.48682 & -17.84715 & -19.70191 \\
3 & 387.0475 & 45.20225 & $2.22 \mathrm{e}-16$ & -22.74426 & -18.90475 & -21.60257 \\
4 & 474.8438 & $39.02057^{*}$ & $1.20 \mathrm{e}-17^{*}$ & $-27.39584^{*}$ & $-22.35647^{*}$ & $-25.89737^{*}$ \\
\hline
\end{tabular}



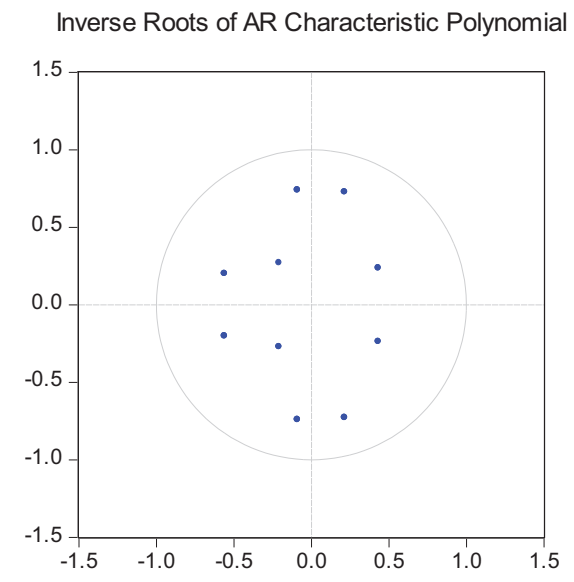

Figure 1 AR root in the VAR model

The Johansen cointegration test results show that the hypothesis that there is no cointegration relation is rejected at the 5\% significance level and the assumption that there are at most 3 cointegrating relationships is accepted. A standardized cointegration equation is as follows:

$Y=0.621492 \Delta I F N+0.234525 \Delta F I N+1.423354 \Delta P I-2.400229 \Delta F S A+C$

From the cointegration equation, there is a long-term and stable positive relationship between formal and informal finance in rural areas and per capita net income of rural peasants. Compared with formal financial scale, this paper shows that rural informal financial scale has an effect on promoting the increase of farmer's household income, there may be two reasons: First, the sample time span of this paper for the 1984-2015, the early reform of China through industrial and agricultural price scissors in the form of feeding industry, until the end of 2004, China gradually increased the three rural Support for rural financial reform and innovation. Second, farmers financing loans, with the characteristics of a wide range of time and seasonal, rural financial institutions take into account the cost of formal factors, risk and other factors, the regional unit, the financial needs of the main demand for loans to deal with the bulk business is difficult to meet These diversified financing deadlines are required.

The level of financial support for agriculture and family business income growth there is a negative relationship. The reasons for this phenomenon may be as follows: First, the local financial support of the small amount of funds to support agriculture, to promote comprehensive reform to improve the livelihood of the small proportion of funds for the promotion of farmer's household income is of little significance. Second, there are many departments involved in financial support for agriculture, overlapping institutions, lack of effective coordination mechanism, integration effect and poor support effect.

The investment of various fixed assets of agriculture can play a positive role in guaranteeing the steady growth of farmer's household income while reducing the 
risks of production and operation of agricultural products. The level of investment in fixed assets and farmers' family business significant positive correlation between sexual incomes.

\subsection{Impulse response analysis based on VAR model}

This paper examines the impact of rural informal finance on the growth of farmer's household income. The VAR model between HI and IFN was established, and the impulse response analysis function was used to further analyze the specific effect of this causal relationship.

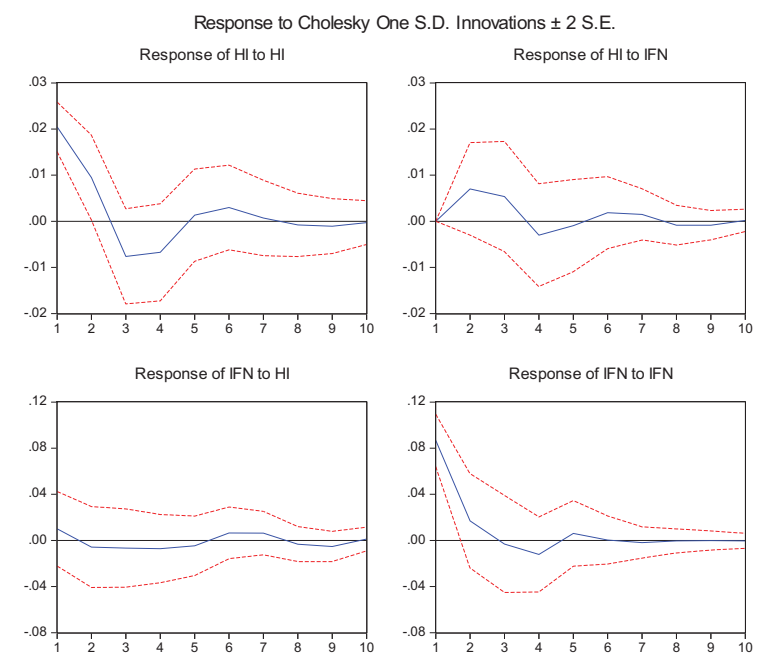

Figure 2 Farmer's household income, rural informal financial information volatility response curve

Figure 2 can be found: First, the farmer's household income in the short term will have positive effects on the positive impact of rural informal financial scale, the positive response in the lagged two to reach the maximum, lagged four to negative, Then gradually converge. In the long run, farmer's household income has a positive effect on one standard deviation of rural informal financial scale, but the positive effect is smaller, probably due to the seasonal and cyclical nature of agricultural production, The majority of farmers borrowing mainly for shortterm loans, formal financial credit constraints so that rural informal finance can effectively alleviate the peasant temporary consumption expenditure on production investment funds crowding out effect, stable production and operation investment, short-term on family business income influences. Second, the positive impact of farmer's household income has positive effect on rural informal finance in the first two periods, and then gradually converges. However, the positive effect is small in the whole, which shows that in the short run peasant household, the scale of the informal finance has a smaller pulling effect. Because of the short-term loan between farmers and the short time between the borrowing and the collection of funds, it is possible for the rural informal finance to increase 
the income from the family business income Of the forward response period is shorter. The most important function of informal finance in rural areas is to transform the idle investment in the rural areas outside the rural financial system into the intermediary function of the loan. The effect of intermediary efficiency is mainly reflected in its own information technology construction. In rural areas with better information, Formal financial market, intermediary efficiency is higher, the increase of family business income can expand the scale of rural informal finance in the short term, make it play a better intermediary function, and become a useful complement to formal finance.

\subsection{Variance decomposition}

The purpose of variance decomposition is to evaluate the importance of the impact of endogenous variables by analyzing the contributions of endogenous variables. The results of variance decomposition based on VAR model (Table 5) show that the contribution rate of non-formal financial scale is relatively stable except for the impact of household income in rural households, which is $7.98 \%$ in the second period. The variance of $7.98 \%$ of the variance of farmers' household income can be explained by the change of informal financial scale, and the period is gradually increased, and the fourth period is stabilized at about $10 \%$. The contribution rate of formal financial scale change is only $2.77 \%$ in the second period, which means that the variance of the farmer's household income of rural households can be explained by the change of the formal financial scale, and the contribution rate of the second period is increasing year by year Trend, after the first 6 phase began to slow down, stabilized at around 4\%. This shows to a certain extent that in recent years China's rural financial system reform and new rural financial development has been effective, but the reform still needs in-depth.

The contribution rate of per capita fixed asset investment ratio was $6.77 \%$ in the second period, and the contribution rate steadily increased to about $12 \%$. The contribution rate of the level of financial support to agriculture increased from $0.06 \%$ to about $3 \%$ and gradually stabilized. Comparatively speaking, the income of financial support for family business income has little effect, we should continue to increase the intensity of financial support to agriculture, especially to the innovation of financial supply mechanism of agriculture.

\section{Conclusions and suggestions}

The conclusion is as follows: First, rural informal finance promotes the increase of farmer's household income, and the income effect is stable. Second, compared with the rural formal finance, the informal financial scale has a significant effect on improving the farmer's household income. Thirdly, in the long run, the scale of informal finance in rural areas in China has a relatively limited impact on the income of peasant households. Fourthly, the level of investment in fixed assets is positively correlated with the income of peasant households, while the level of fiscal support is negatively correlated. Fifth, the variance decomposition results 
show that China's rural financial reform to some extent to achieve some success, but the reform is still a long way.

In view of this, in order to give full play to the positive effects of rural informal finance on improving the income of farmer's households, the following policy suggestions are put forward in order to provide reference: First, it is necessary to further liberalize rural informal financial development in rural financial policy. And give the rural informal finance a clearer development orientation and policy support to guide and encourage the healthy development of rural informal finance. Second, it is necessary to establish and improve risk prevention and control and compensation mechanism for rural informal finance, promote market-oriented interest rate reform, and strengthen regulation of informal financial risks. The third is to promote the deepening reform of rural finance as a whole, to promote the farmers' housing property rights and the right to operate rural land contract and other "two rights" mortgage pilot to explore the establishment of agricultural income insurance system and the implementation of agricultural production facilities, mortgage loans, and actively tap the rural formal finance In the promotion of farmers on the potential income.

\section{Acknowledgement}

Fund Project: Sichuan Province, Department of Education Key Projects "from the perspective of synergies Sichuan Pratt \& Whitney rural financial institutions, products and services innovation" (16SA0009);

National Undergraduate Innovation and Entrepreneurship Training Program

Project "Rural informal finance impact on farmers' productive income of the empirical analysis"

\section{References}

[1] Hu Zongyi, Liu Can, Liu Yewen. Rural formal financial and informal financial development of rural residents' income effect. Journal of Economic Geography, 34 (12), pp. 147-152, 2014

[2] Adams, D. \& Fichett, D. Informal Finance in Low Income Countries [M]. Boulder, CO.: West View Press, 1992: 5.

[3] Song Kun. Rural private finance and formal financial cooperation model of empirical research. Macroeconomic, 6(24), pp. 143-159, 2016 